\title{
Use of herbal formulations for the treatment of circumcision wounds in Eastern and Southern Africa
}

\author{
Alfred Maroyi \\ Department of Botany, University of Fort Hare, Private Bag X1314, Sovenga 0727, South Africa \\ *Email: amaroyi@ufh.ac.za
}

\section{ARTICLE HISTORY}

Received: 07 February 2021

Accepted: 08 April 2021

Available online: 01 July 2021

\section{KEYWORDS}

Eastern and Southern Africa

Ethnopharmacology

Indigenous knowledge

Medicinal plants

Traditional male circumcision

\begin{abstract}
Medicinal plants used to treat and manage circumcision wounds have remained an integral part of traditional practice in Eastern and Southern Africa. This study reviews the traditional usage of medicinal plants to treat and manage circumcision wounds in Eastern and Southern Africa. Drawing on data from Kenya, Namibia, South Africa and Tanzania, information was collected from different sources including books, theses and electronic scientific search engines such as Scopus, Science Direct, PubMed, SciFinder and Google Scholar. A literature search was also undertaken focusing on medicinal plants used against circumcision wounds that demonstrated antibacterial and anti-inflammatory activities in in vitro studies. Twenty-eight medicinal plants from 15 families are recorded as traditional therapies for circumcision wounds following an extensive literature search. These species used to treat and manage circumcision wounds, and as dressing after circumcision to prevent serious inflammation are mainly (64.3\%) members of Amaryllidaceae, Asparagaceae, Asteraceae, Euphorbiaceae and Fabaceae families. Three quarters (75.0\%) of these species including Acalypha ornata, Achyranthes aspera, Asparagus africanus, Boophone disticha, Brunsvigia grandiflora, Burkea africana, Colophospermum mopane, Datura stramonium, Dichrostachys cinerea, Helichrysum appendiculatum, H. foetidum, H. longifolium, H. nudifolium, H. pedunculatum, Lippia javanica, Maesa lanceolata, Ptaeroxylon obliquum, Ricinus communis, Searsia natalensis, Triumfetta rhomboidea and Vachellia nilotica have shown antibacterial and anti-inflammatory effects in a set of in vitro models. Further studies are needed such as isolation of phytochemical compounds, in vivo activities, clinical and toxicological studies.
\end{abstract}

\section{Introduction}

Traditional male circumcision is an important cultural ritual in Eastern and Southern Africa. Male circumcision is carried out for cultural reasons, as an initiation ritual and a rite of passage or transition from boyhood to manhood (1-4). Generally, boys would be taken away from their homes with or without the permission of the head of the families and kept in a secluded place where they will be circumcised and kept for a period of two to four weeks to allow the healing process (1). In Eastern and Southern Africa, traditional male circumcision is seen as a sacred cultural practice, rationalised as a mechanism for the maintenance of social order, associated with ascribed cultural teachings and performance of sexual rites that are sanctioned by society $(4,6,7)$. Approximately $15 \%$ of the males aged 15 years or older in Kenya, Namibia, South Africa and Tanzania are circumcised (8-10). However, an estimated $84 \%$ of all Kenyan men are circumcised but the percentage is much lower among the Luo and Turkana ethnic groups with $17 \%$ and $40 \%$, respectively (10). In South Africa, several ethnic groups practice male circumcision as a rite of passage from boyhood to manhood and these include Ndebele, Pedi, Sotho, Tsonga, Venda and Xhosa $(7,11)$. The traditional male circumcision procedure is usually performed in a non-clinical setting by a traditional provider with no formal medical training. When carried out as a rite of passage into manhood, traditional male circumcision is mainly performed on adolescents or in early adult life as a shift to puberty, adulthood or marriage (12-15). Male circumcision is one of the oldest surgical procedures known, and ritual circumcision is the act of severance of the foreskin without anaesthesia $(11,16-18)$. Once the foreskin is cut off, the wound is not stitched but bound in traditional medicines to help in the healing process (19-23). Therefore, traditional male circumcision procedure relies heavily on traditional medicines to

(c) Maroyi (2021). This is an open-access article distributed under the terms of the Creative Commons Attribution License, which permits unrestricted use, distribution and reproduction in any medium, provided the original author and source are credited (https://creativecommons.org/licenses/by/4.0/). 
prevent microbial infections, ameliorate swelling and pains, and accelerate wound healing.

Research into medicinal uses, phytochemistry and pharmacological properties of medicinal plants used to treat and manage circumcision wounds offers tremendous potential for developing new pharmaceutical health products and drugs. Although conventional medical circumcision is popular in some urban African cities as the World Health Organisation (WHO) recommended male circumcision as part of a comprehensive programme for preventing human immunodeficiency virus (HIV) transmission in areas with high endemic rates (2431), traditional male circumcision is still widely practised in Eastern and Southern Africa (1-4). Studies are there (29) arguing that the emergency of HIV has brought the ancient traditional male circumcision on spot light as a result of recent studies which have demonstrated that it does not only reduce the rate of HIV infection but the ancient procedure also reduces penile cancer and cervical cancer. This has led to massive male circumcision campaigns in areas with low prevalence of circumcision. However, utilization of traditional medicines will continue to be an important approach to male circumcision in peri-urban, rural and marginalized areas characterized by limited conventional medical services. Moreover, research (32) revealed that medicinal plants are an important component of the daily lives of many people and an important part of the African cultural heritage, and $50 \%$ of pharmaceutical drugs and health products in clinical use in the world are derived from natural products isolated from plants. Some of these examples include aspirin derived from a compound called salicin isolated from Salix alba L., artemisin from Artemisia annua L., opium obtained from Papaver somniferum L., paclitaxel from Taxus brevifolia Nutt., quinine, an alkaloid obtained from Cinchona pubescens Vahl and silymarin from Silybum marianum (L.) Gaertn. (32). The ongoing screening of ethnopharmacological properties of Eastern and Southern African plants generated active principles that have great potential in the fight against several global health problems (33-38). This study, therefore, was aimed at reviewing the traditional usage of medicinal plants to treat and manage circumcision wounds in Eastern and Southern Africa focusing on Kenya, Namibia, South Africa and Tanzania.

\section{Materials and Methods}

A systematic search for medicinal plants used to treat and manage circumcision wounds in Kenya, Namibia, South Africa and Tanzania (Fig. 1) was undertaken using a variety ethnobotanical and ethnopharmacological books $(32,40-45)$ and other ethnobotanical pre-electronic sources such as book chapters, journal articles and scientific publications obtained from the University of Fort Hare library. The research articles were searched using Scopus, Science Direct, PubMed, SciFinder and Google Scholar using the following terms as filters, and were searched both alone and as combinations: "circumcision", "circumcision wounds",

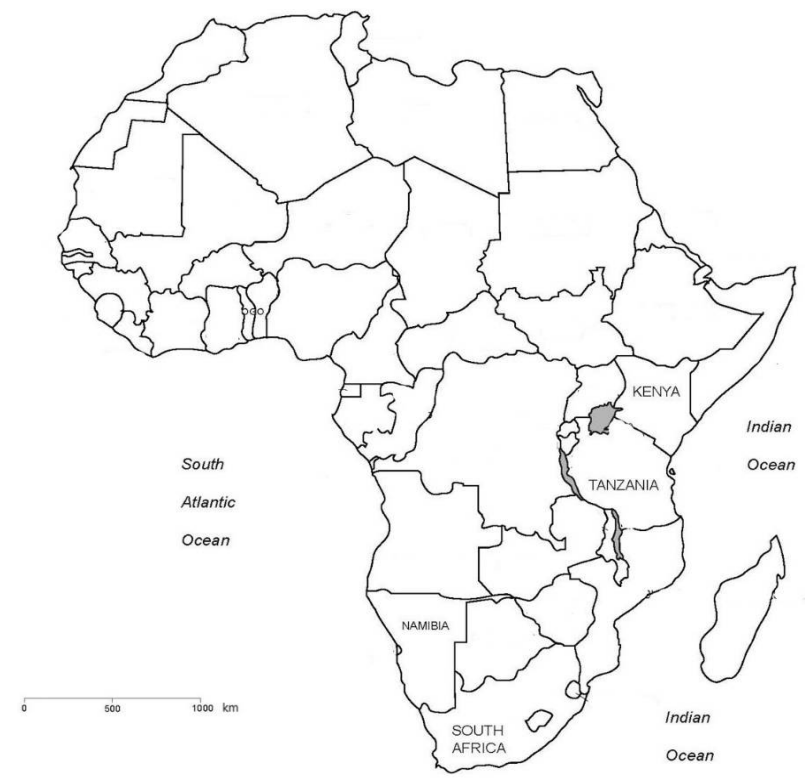

Fig. 1. Geographical location of the study area-Kenya, Namibia, South Africa and Tanzania.

"ethnobotany", "medicinal plant”, "Kenya”, "Namibia", "South Africa", "Tanzania" and "traditional medicine”. Each plant species identified by this initial search was subjected to a further literature review to establish its antibacterial and anti-inflammatory activities in in vitro studies. All filtered articles were appraised to determine whether they contain any validated in vitro antibacterial and anti-inflammatory models. Where possible, the common and vernacular names were collected, and all scientific names were confirmed or updated using the Plant List website (http://www.theplantlist.org/). A total of 176 articles published between 1938 and 2021 matched the inclusion criteria and were included in this review (Fig. 2).

\section{Results and Discussion}

\section{Medicinal plant diversity}

Twenty-eight medicinal plant species from 15 families are recorded as traditional therapies for circumcision wounds in Kenya, Namibia, South

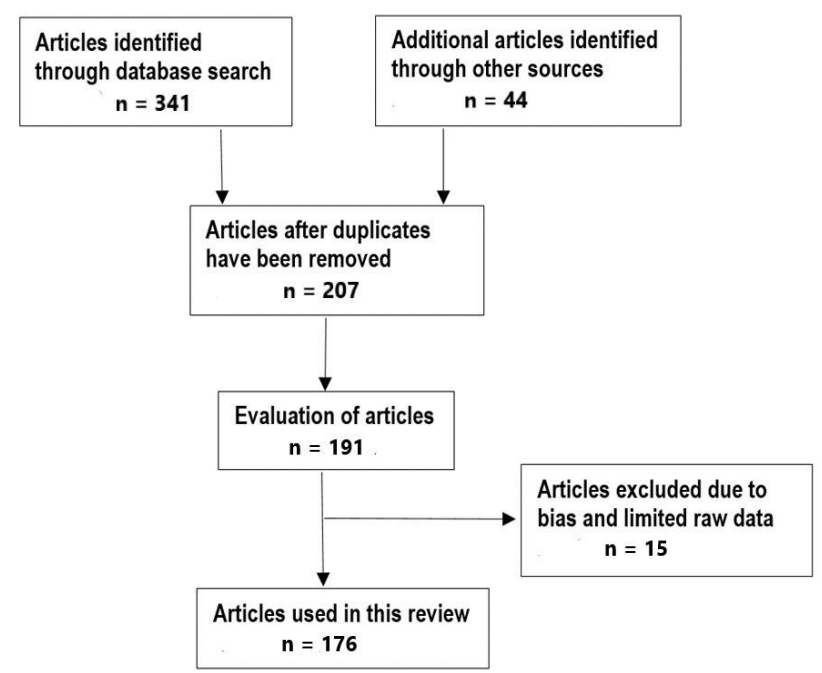

Fig. 2. Flow diagram with the number of selected articles. 
Africa and Tanzania following an extensive literature search (Table 1). The preparation methods and application of these species are well documented in the common ethnobotanical literature (32, 39, 40, 44, 45). Generally, the use of these medicinal plants in traditional medicine among ethnic groups in the region is well-known. Only two species, Datura stramonium L. and Ricinus communis L. are exotic in the region and naturalized as weeds (46). These results imply that local communities in Eastern and
Southern Africa have enriched their indigenous pharmacopoeia through utilization of exotic and weedy plant species as traditional medicines for circumcision wounds. Previous research on exotic plant species showed that these species are utilized as medicinal plants throughout the world (47-52). Exotic plants are used as traditional medicines due to their use-versatility applications (53). The majority of medicinal plants (64.3\%) used against circumcision wounds are from five families (Fig. 3), and these are

Table 1. Medicinal plants used traditionally to treat circumcision wounds in Kenya, Namibia, South Africa and Tanzania. An asterisk $\left({ }^{*}\right)$ indicates that the species is known or believed to be exotic and naturalized in the region (46).

\begin{tabular}{|c|c|c|c|c|}
\hline $\begin{array}{c}\text { Scientific name and } \\
\text { family }\end{array}$ & Common name(s) & Country & Used for & $\begin{array}{l}\text { Referenc } \\
\text { e(s) }\end{array}$ \\
\hline $\begin{array}{l}\text { Acalypha ornata } \\
\text { Hochst. ex A. Rich. } \\
\text { (Euphorbiaceae) }\end{array}$ & $\begin{array}{l}\text { Mfulwe (Bondei), mfulwe, msindo (Sambaa, Zigua), } \\
\text { huhunga (Sukuma), mchacha (Swahili), lushete } \\
\text { (Tongwe), }\end{array}$ & Tanzania & $\begin{array}{l}\text { Leaf powder applied on } \\
\text { circumcision wounds }\end{array}$ & (42) \\
\hline $\begin{array}{l}\text { Achyranthes aspera } \\
\text { L. (Amaranthaceae) }\end{array}$ & $\begin{array}{l}\text { Devil's horsewhip (English), kiandama (Sambaa), } \\
\text { pulule, turura (Swahili) }\end{array}$ & Tanzania & $\begin{array}{l}\text { Leaves used as dressing } \\
\text { after circumcision }\end{array}$ & (54) \\
\hline $\begin{array}{l}\text { Aneilema } \\
\text { pedunculosum C.B. } \\
\text { Clarke } \\
\text { (Commelinaceae) }\end{array}$ & Mukengeria (Kikuyu) & Kenya & $\begin{array}{l}\text { Leaves used as dressing } \\
\text { after circumcision }\end{array}$ & (43) \\
\hline $\begin{array}{l}\text { Anthoxanthum } \\
\text { ecklonii (Nees ex } \\
\text { Trin.) Stapf (Poaceae) }\end{array}$ & Sweet vernal and sweet vernal grass (English) & $\begin{array}{l}\text { South } \\
\text { Africa }\end{array}$ & $\begin{array}{l}\text { Whole plant used as } \\
\text { dressing after circumcision }\end{array}$ & (44) \\
\hline $\begin{array}{l}\text { Asparagus africanus } \\
\text { Lam. (Asparagaceae) }\end{array}$ & $\begin{array}{l}\text { Haakdoring, katdoring, wag-'n-bietjie (Afrikaans), } \\
\text { African asparagus, bush asparagus, climbing } \\
\text { asparagus fern, ornamental asparagus, sparrow } \\
\text { grass, wild asparagus (English), empere-epapa, } \\
\text { olomei (Maasai), lelala-tau-le-leholo, leunyeli } \\
\text { (Sotho), ubulawu ubumhlope, umathunga, umthunzi } \\
\text { (Xhosa), isigoba, isigobo (Zulu) }\end{array}$ & $\begin{array}{l}\text { Kenya } \\
\text { and South } \\
\text { Africa }\end{array}$ & $\begin{array}{l}\text { Root powder inserted into } \\
\text { scarifications on legs to } \\
\text { give strength and } \\
\text { fearlessness while leaves } \\
\text { and roots are used to clean } \\
\text { circumcision wounds }\end{array}$ & $\begin{array}{l}(40,41,45 \\
55,56)\end{array}$ \\
\hline $\begin{array}{l}\text { Boophone disticha } \\
\text { (L.f.) Herb. } \\
\text { (Amaryllidaceae) }\end{array}$ & $\begin{array}{l}\text { Boesmangif, gifbol, kopseerblom, perdespook, } \\
\text { seeroogblom (Afrikaans), bushman poison bulb, } \\
\text { century plant, poison bulb, sore-eye flower } \\
\text { (English), kxutsana-yanaha, leshoma, motlatsisa } \\
\text { (Sotho) leshoma Tswana), incwadi, incotho (Xhosa, } \\
\text { Zulu), ibhade (Zulu) }\end{array}$ & $\begin{array}{l}\text { South } \\
\text { Africa }\end{array}$ & $\begin{array}{l}\text { Outer scales of the bulb } \\
\text { and leaves used as dressing } \\
\text { after circumcision }\end{array}$ & $\begin{array}{l}(21,32,39 \\
40,57-63)\end{array}$ \\
\hline $\begin{array}{l}\text { Brunsvigia } \\
\text { grandiflora Lindl. } \\
\text { (Amaryllidaceae) }\end{array}$ & $\begin{array}{l}\text { Kandelaarblom (Afrikaans), giant candelabra flower } \\
\text { (English), isichwe (Xhosa), umqhele-wenkunzi (Zulu) }\end{array}$ & $\begin{array}{l}\text { South } \\
\text { Africa }\end{array}$ & $\begin{array}{l}\text { Leaves used as a bandage } \\
\text { and outer bulb scales used } \\
\text { for dressing after } \\
\text { circumcision for rapid } \\
\text { healing }\end{array}$ & $\begin{array}{l}(40,62,64- \\
66)\end{array}$ \\
\hline $\begin{array}{l}\text { Burkea africana } \\
\text { Hook. (Fabaceae) }\end{array}$ & $\begin{array}{l}\text { Wildesering (Afrikaans), wild seringa (English), } \\
\text { mpulu (Tsonga), monato (Sotho, Tswana), mufhulu } \\
\text { (Vemba) }\end{array}$ & $\begin{array}{l}\text { South } \\
\text { Africa }\end{array}$ & $\begin{array}{l}\text { Leaf maceration applied on } \\
\text { wounds }\end{array}$ & $(67,68)$ \\
\hline $\begin{array}{l}\text { Colophospermum } \\
\text { mopane (J. Kirk ex } \\
\text { Benth.) J. Kirk ex J. } \\
\text { Léonard (Fabaceae) }\end{array}$ & $\begin{array}{l}\text { Mopani (Afrikaans, Silozi), //gais (Ju_Hoan), //gais, } \\
\text { tsaurahais (Khoekhoegowab), pana (Kxoe), omutati } \\
\text { (OtjiHerero), mupanyi (Thimbukushu) }\end{array}$ & Namibia & $\begin{array}{l}\text { Leaf fibre chewed and } \\
\text { applied on circumcision } \\
\text { wounds }\end{array}$ & $(69,70)$ \\
\hline $\begin{array}{l}\text { Crossyne guttata (L.) } \\
\text { D. Müll.-Doblies \& U. } \\
\text { Müll.-Doblies } \\
\text { (Amaryllidaceae) }\end{array}$ & $\begin{array}{l}\text { Sambreelblom (Afrikaans), April fool lily, parasol } \\
\text { lily (English) }\end{array}$ & $\begin{array}{l}\text { South } \\
\text { Africa }\end{array}$ & $\begin{array}{l}\text { Bulb powder applied } \\
\text { topically after circumcision } \\
\text { rites, stitches deep cuts and } \\
\text { draws out puss }\end{array}$ & (71) \\
\hline $\begin{array}{l}\text { *Datura stramonium } \\
\text { L. (Solanaceae) }\end{array}$ & $\begin{array}{l}\text { Stinkblaar (Afrikaans), stinkweed, thorn apple } \\
\text { (English), lechoe, lethsowe (Sotho), zaba-zaba } \\
\text { (Tsonga), ijoyi, umhlabavuthwa (Xhosa), iloqi, iloyi } \\
\text { (Zulu) }\end{array}$ & $\begin{array}{l}\text { South } \\
\text { Africa }\end{array}$ & $\begin{array}{l}\text { Leaves used as a bandage } \\
\text { and to sooth the pain and } \\
\text { swelling and as antiseptic } \\
\text { after circumcision }\end{array}$ & (72) \\
\hline $\begin{array}{l}\text { Dichrostachys cinerea } \\
\text { (L.) Wight \& Arn. } \\
\text { (Fabaceae) }\end{array}$ & $\begin{array}{l}\text { Sekelbos (Afrikaans), bastard Acacia, sickle bush } \\
\text { (English), lereche, moretse, mtundulu (Kigogo), } \\
\text { olmerumuri (Maasai), moselesele (Sotho), mkingiri, } \\
\text { msigino (Swahili), keye, moselesele (Tswana), } \\
\text { murenzhe, muunga (Venda), ugegane, umthezane } \\
\text { (Zulu) }\end{array}$ & $\begin{array}{l}\text { South } \\
\text { Africa } \\
\text { and } \\
\text { Tanzania }\end{array}$ & $\begin{array}{l}\text { Bark powder applied } \\
\text { topically on circumcision } \\
\text { wounds }\end{array}$ & $(45,73)$ \\
\hline $\begin{array}{l}\text { Drimia capensis } \\
\text { (Burm.f.) Wijnands } \\
\text { (Asparagaceae) }\end{array}$ & Maerman (Afrikaans) & $\begin{array}{l}\text { South } \\
\text { Africa }\end{array}$ & $\begin{array}{l}\text { Bulb powder applied } \\
\text { topically after circumcision } \\
\text { rites, stitches deep cuts and } \\
\text { draws out puss. }\end{array}$ & (71) \\
\hline $\begin{array}{l}\text { Gymnosporia } \\
\text { heterophylla (Eckl. \& } \\
\text { Zeyh.) Loes. } \\
\text { (Celastraceae) }\end{array}$ & $\begin{array}{l}\text { Common spike-thorn bush (English), muthuthi } \\
\text { (Kikuyu), olaimoronyai, olaimurunyai (Maasai), } \\
\text { mdungu-mdeewe (Swahili), ekalamoran (Turkana) }\end{array}$ & Kenya & $\begin{array}{l}\text { Bark, roots, stems and } \\
\text { twigs powder applied } \\
\text { topically after circumcision } \\
\text { rites }\end{array}$ & $(41,56)$ \\
\hline $\begin{array}{l}\text { Helichrysum } \\
\text { appendiculatum Less. } \\
\text { (Asteraceae) }\end{array}$ & $\begin{array}{l}\text { Skaapoorbossie (Afrikaans), sheep's ears everlasting } \\
\text { (English), senkotoana (Sotho), ibode, indlebeyemvu } \\
\text { (Zulu) }\end{array}$ & $\begin{array}{l}\text { South } \\
\text { Africa }\end{array}$ & $\begin{array}{l}\text { Fresh leaves used as } \\
\text { antiseptic to induce fast } \\
\text { healing after circumcision } \\
\text { to prevent external } \\
\text { inflammation }\end{array}$ & $\begin{array}{l}(57,58,74- \\
76)\end{array}$ \\
\hline
\end{tabular}




\begin{tabular}{|c|c|c|c|c|}
\hline $\begin{array}{l}\text { Helichrysum crispum } \\
\text { D. Don (Asteraceae) }\end{array}$ & $\begin{array}{l}\text { Hotnotskooigoed, } \\
\text { hottentotskruie, kooigoed (Afrikaans), hottentot's } \\
\text { bedding (English) }\end{array}$ & $\begin{array}{l}\text { South } \\
\text { Africa }\end{array}$ & $\begin{array}{ll}\text { Leaves used } & \text { as a } \\
\text { circumcision } & \text { wound } \\
\text { dressing } & \\
\end{array}$ & (40) \\
\hline $\begin{array}{l}\text { Helichrysum foetidum } \\
\text { Moench (Asteraceae) }\end{array}$ & $\begin{array}{l}\text { Geelsewejaartjie, muishondblaar, vleisewejaartjie } \\
\text { (Afrikaans), stinking strawflower, stinking yellow } \\
\text { everlasting (English), isicwe (Zulu) }\end{array}$ & $\begin{array}{l}\text { South } \\
\text { Africa }\end{array}$ & $\begin{array}{ll}\text { Leaves used } & \text { as a } \\
\text { circumcision } & \text { wound } \\
\text { dressing } & \\
\end{array}$ & $(40,77-79)$ \\
\hline $\begin{array}{l}\text { Helichrysum } \\
\text { longifolium DC. } \\
\text { (Asteraceae) }\end{array}$ & Kooigoed (Afrikaans), Everlasting (English) & $\begin{array}{l}\text { South } \\
\text { Africa }\end{array}$ & $\begin{array}{l}\text { Leaves used to treat } \\
\text { circumcision wounds and } \\
\text { as dressing after } \\
\text { circumcision }\end{array}$ & $(20,57)$ \\
\hline $\begin{array}{l}\text { Helichrysum } \\
\text { nudifolium (L.) Less. } \\
\text { (Asteraceae) }\end{array}$ & $\begin{array}{l}\text { Hottentotsteebossie, kooigoed } \\
\text { everlastings (English), isicwe, indlebe } \\
\text { undleni (Xhobhoaks), icholocholo, imphepho, isidwaba- } \\
\text { somkhovu (Zulu) }\end{array}$ & $\begin{array}{l}\text { South } \\
\text { Africa }\end{array}$ & $\begin{array}{l}\text { Leaves used to treat } \\
\text { circumcision wounds and } \\
\text { as dressing after } \\
\text { circumcision }\end{array}$ & $\begin{array}{l}(32,40,63 \\
64,66,80- \\
82)\end{array}$ \\
\hline $\begin{array}{l}\text { Helichrysum } \\
\text { pedunculatum } \\
\text { Hilliard \& B.L. Burtt } \\
\text { (Asteraceae) }\end{array}$ & $\begin{array}{l}\text { Kooigoed (Afrikaans), everlastings (English), isicwe } \\
\text { (Xhosa), imphepho (Zulu) }\end{array}$ & $\begin{array}{l}\text { South } \\
\text { Africa }\end{array}$ & $\begin{array}{l}\text { Leaves used to treat } \\
\text { circumcision wounds and } \\
\text { as dressing after } \\
\text { circumcision to prevent } \\
\text { serious inflammation }\end{array}$ & $\begin{array}{l}(19- \\
21,23,39,5 \\
7,63,66,76, \\
77,81,83- \\
88)\end{array}$ \\
\hline $\begin{array}{l}\text { Lippia javanica } \\
\text { (Burm. f.) Spreng. } \\
\text { (Verbenaceae) }\end{array}$ & $\begin{array}{l}\text { Beukesbossie, koorsbossie, lemoenbossie } \\
\text { (Afrikaans), efurie (Chagga), fever tree, lemon bush, } \\
\text { wild tea (English), olsinoni (Maasai), muthiriti } \\
\text { (Kikuyu, Meru), mvuti (Swahili, Zigua), mvudi } \\
\text { (Taita), bokhukhwane, musukudu (Tswana), } \\
\text { inzinziniba (Xhosa), umswazi, umsuzwane (Zulu) }\end{array}$ & $\begin{array}{l}\text { Kenya } \\
\text { and South } \\
\text { Africa }\end{array}$ & $\begin{array}{l}\text { Whole plant placed on a } \\
\text { patient's bed after the } \\
\text { circumcision to prevent } \\
\text { odours and freshen } \\
\text { surrounding air }\end{array}$ & $(55,89,90)$ \\
\hline $\begin{array}{l}\text { Maesa lanceolata } \\
\text { Forssk. (Primulaceae) }\end{array}$ & $\begin{array}{l}\text { Valsassegaai (Afrikaans), false assegai (English), } \\
\text { intendekhane (Xhosa), muunguri (Venda), isidenda, } \\
\text { ubhoqobhoqo, umagupu, umalunguzalazikhakhona, } \\
\text { inhlavubele (Zulu) }\end{array}$ & $\begin{array}{l}\text { South } \\
\text { Africa }\end{array}$ & $\begin{array}{l}\text { Leaves used for dressing } \\
\text { circumcision wounds }\end{array}$ & $(40,91)$ \\
\hline $\begin{array}{l}\text { Ptaeroxylon obliquum } \\
\text { (Thunb.) Radlk. } \\
\text { (Rutaceae) }\end{array}$ & $\begin{array}{l}\text { Nieshout (Afrikaans), sneezewood (English), thate } \\
\text { (Tswana), umthathi, umthote (Xhosa), mulari, } \\
\text { munari, munukha-vhaloi (Venda), umthathe (Zulu) }\end{array}$ & $\begin{array}{l}\text { South } \\
\text { Africa }\end{array}$ & $\begin{array}{l}\text { Leaves used as a bandage } \\
\text { to sooth pain and swelling } \\
\text { after circumcision }\end{array}$ & (92) \\
\hline $\begin{array}{l}\text { *Ricinus communis L. } \\
\text { (Euphorbiaceae) }\end{array}$ & $\begin{array}{l}\text { Bloubottelboom, bosluisie, } \text { kasterolieboom } \\
\text { (Afrikaans), castor bean, castor oil plant (English), } \\
\text { mohlafotha, mokhura (Sotho), nhlampfura } \\
\text { (Tswana), muplure (Venda), umhlakuva (Xhosa, } \\
\text { Zulu) }\end{array}$ & $\begin{array}{l}\text { South } \\
\text { Africa }\end{array}$ & $\begin{array}{l}\text { Leaves used as a bandage } \\
\text { to sooth pain and swelling } \\
\text { and as antiseptic after } \\
\text { circumcision }\end{array}$ & (72) \\
\hline $\begin{array}{l}\text { Scadoxus multiflorus } \\
\text { (Martyn) Raf. } \\
\text { (Amaryllidaceae) }\end{array}$ & $\begin{array}{l}\text { Bloedblom, gifwortel (Afrikaans), blood flower, } \\
\text { fireball lily, katharine wheel, poison root (English), } \\
\text { inkupulwane (Xhosa), idunjana, ubukhoswane } \\
\text { (Zulu) }\end{array}$ & $\begin{array}{l}\text { South } \\
\text { Africa }\end{array}$ & $\begin{array}{l}\text { Outer scales of the bulb } \\
\text { and leaves used as dressing } \\
\text { after circumcision }\end{array}$ & (21) \\
\hline $\begin{array}{l}\text { Searsia natalensis } \\
\text { (Bernh. ex C. Krauss) } \\
\text { F.A. Barkley } \\
\text { (Anacardiaceae) } \\
\end{array}$ & $\begin{array}{l}\text { Natal karree, Natal rhus (English), muthigiyu, } \\
\text { muthiigi (Kikuyu, Mbeere), ormisigiyioi, ormisigiyoi } \\
\text { (Maasai), mhunguru (Sambaa, Sukuma), mkono } \\
\text { chuma, mvunja kondo (Swahili), kitarika (Taita) }\end{array}$ & Kenya & $\begin{array}{l}\text { Leaf powder applied on } \\
\text { circumcision wounds }\end{array}$ & $(39,55)$ \\
\hline $\begin{array}{l}\text { Triumfetta } \\
\text { rhomboidea Jacq. } \\
\text { (Tiliaceae) }\end{array}$ & $\begin{array}{l}\text { Burbush, burweed, Chinese bur, diamond burbark, } \\
\text { paroquet bur (English), mboshoko (Pare), } \\
\text { mchokochole, mchokochore, mfyokochore (Swahili), } \\
\text { mfungang’ombe (Zigua) }\end{array}$ & $\begin{array}{l}\text { Kenya } \\
\text { and } \\
\text { Tanzania }\end{array}$ & $\begin{array}{l}\text { Roots used for treating } \\
\text { circumcision wounds }\end{array}$ & $(43,93,94)$ \\
\hline $\begin{array}{l}\text { Vachellia nilotica }(\mathrm{L} .) \\
\text { P.J.H. Hurter \& Mabb. } \\
\text { (Fabaceae) }\end{array}$ & 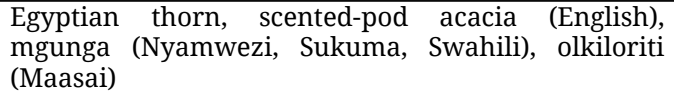 & Tanzania & $\begin{array}{l}\text { Bark powder applied on } \\
\text { circumcision wounds }\end{array}$ & (95) \\
\hline
\end{tabular}

Asparagaceae and Euphorbiaceae (2 species each), Amaryllidaceae and Fabaceae sensu lato (4 species each) and Asteraceae (6 species). The rest of the families are represented by only one species (Fig. 3).

The plant parts used for making herbal preparations used against circumcision wounds are the bark, bulbs, bulb scales, leaf fibre, leaves, roots, stems, twigs and whole plant (Fig. 4). The leaves are the most frequently used (51.0\%), followed by bark and roots $(9.0 \%$ each), bulbs and bulb scales $(8.0 \%$ each), whole plant (6.0\%), leaf fibre, stems and twigs (3.0\% each) (Fig. 4). Based on literature review (1921), Helichrysum pedunculatum Hilliard \& B.L. Burtt, commonly known as Everlastings in English is the most popular medicinal plant used against circumcision wounds in South Africa (Fig. 5) with 18 literature citations, followed by Boophone disticha (L.f.) Herb. and $H$. nudifolium (L.) Less. with 11 and eight literature citations respectively.

More than half $(60.7 \%)$ of the species used to treat and manage circumcision wounds are traded as herbal medicines in local, regional and international

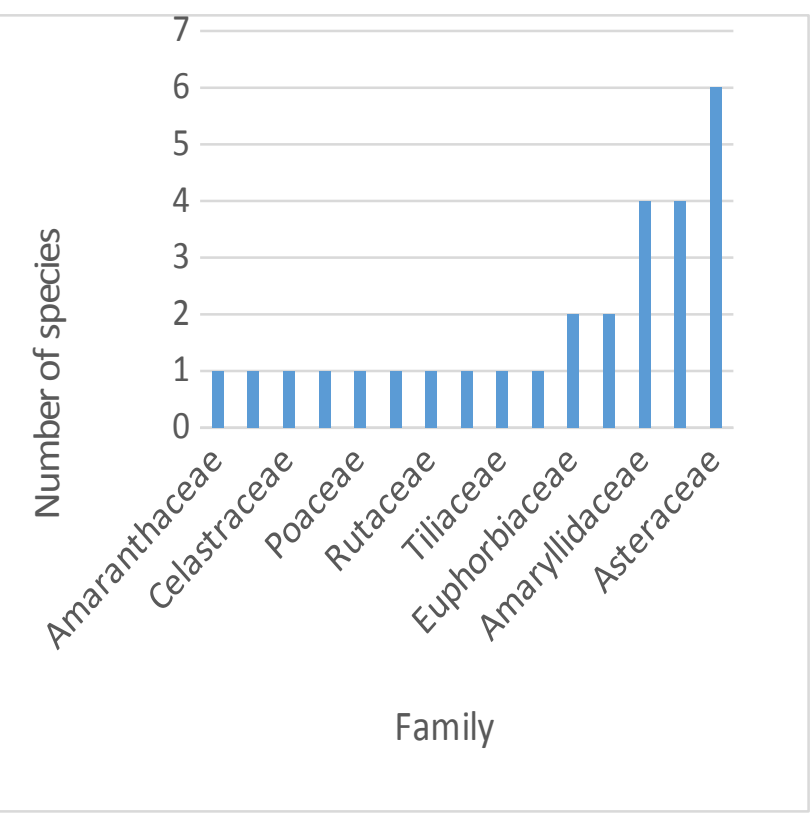

Fig. 3. The number of Eastern and Southern African plant species per family used to treat and manage circumcision wounds. 
markets and these include Achyranthes aspera L., Asparagus africanus Lam., B. disticha, Burkea africana Hook., Colophospermum mopane (J. Kirk ex Benth.) J. Kirk ex J. Léonard, D. stramonium, Dichrostachys cinerea (L.) Wight \& Arn., Drimia capensis (Burm.f.) Wijnands, Gymnosporia heterophylla (Eckl. \& Zeyh.) Loes., H. nudifolium,

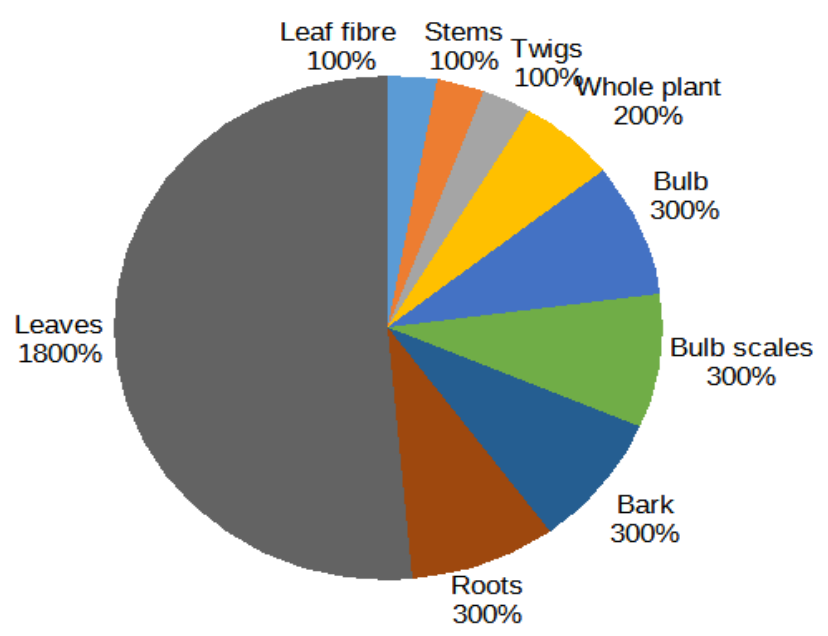

Fig. 4. Frequency of use of different Eastern and Southern African plant parts used to treat and manage circumcision wounds.

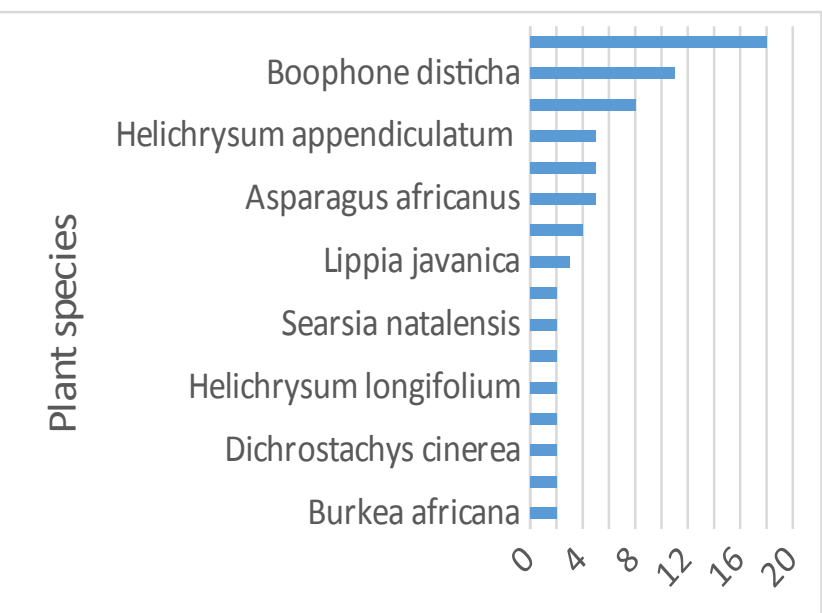

Times found in literature

Fig. 5. Plant species used to treat and manage circumcision wounds in Eastern and Southern Africa.

Lippia javanica (Burm. f.) Spreng., Maesa lanceolata Forssk., Ptaeroxylon obliquum (Thunb.) Radlk., $R$. communis, Searsia natalensis (Bernh. ex C. Krauss) F.A. Barkley, Triumfetta rhomboidea Jacq. and Vachellia nilotica (L.) P.J.H. Hurter \& Mabb. (Table 2). Selling of the bark, bulbs, fruits, leaves, rhizomes, roots, seed oil, stems and whole plant parts of these species in Algeria, Botswana, Burundi, Eswatini, Ethiopia, Lesotho, Malawi, Mozambique, Nigeria, Rwanda, South Africa, South Sudan, Tanzania, Zambia and Zimbabwe generates economic opportunities for vulnerable groups living in periurban, rural and marginalized areas (38, 96-98, 107110). It was observed that there is an increased trade both at domestic and international levels for medicinal plants with known phytopharmaceutical, nutraceutical and cosmeceutical properties (111).

\section{Antibacterial and anti-inflammatory activities}

Many of the ethnobotanical books and primary studies published in journal articles showed that different plant parts are used to treat circumcision wounds and also used as dressing after circumcision to prevent serious inflammation (Table 1). Three quarters (75.0\%) of these species including Acalypha ornata Hochst. ex A. Rich., Achyranthes aspera L., A. africanus, B. distica, Brunsvigia grandiflora Lindl., $B$. africana, C. mopane, D. cinerea, D. stramonium, $H$. appendiculatum, $H$. foetidum, $H$. longifolium, $H$. nudifolium, $H$. pedunculatum, $L$. javanica, $M$. lanceolata, $P$. obliquum, $R$. communis, $S$. natalensis, $T$. rhomboidea and $V$. nilotica have shown antibacterial and anti-inflammatory effects in a set of in vitro models (Supplementary Table 1). All of these species were reported to be effective against one or more bacterial pathogens and also exhibited in vito antiinflammatory activities. It was argued that any medicinal plant species or natural pharmaceutical product to be classified as a good wound healing agent, it should possess antibacterial and antiinflammatory properties among other pharmacological properties $(112,113)$. The wound healing process begins with the polarisation of cells towards the wound, initiation of protrusion and cell migration, which culminate in closure of the wound area $(114,115)$. Most of these plant species used to treat and manage circumcision appear to accelerate the wound healing process. Majority of these species have been as bandages and to sooth the pain and swelling after circumcision for a long time now and are within reasonable reach of the traditional medical practitioners (39). The remaining $25.0 \%$ are yet to be evaluated for in vitro antibacterial and antiinflammatory properties. However, these species which demonstrated promising activities in vitro, should be re-evaluated using appropriate in vivo models. It is thus a future challenge to translate the basic ethnopharmacological knowledge gained from antibacterial and anti-inflammatory assays into meaningful data that can be used to further enhance Eastern and Southern African plants used against circumcision wounds.

\section{Traditional male circumcision is an ancient and common surgical procedure in Eastern and Southern Africa}

Circumcision has existed since time immemorial and is the oldest surgical procedure performed since before recorded history (15). In South Africa, traditional male circumcision ritual dates back to at least 1886 (14). Scholars distinguished three phases of the circumcision rites which include the preparation of the ritual, followed by a process of seclusion and reintegration (7, 161). In the Xhosa cultural circumcision ritual in South Africa, these three stages are clearly identifiable with the initiate (one who undergoes the cultural circumcision ritual) translocated to a temporary hut built which is isolated from the community. Here, the initiate is circumcised and stays for substantial period, during which he heals and is taught about manhood 
Table 2. Eastern and Southern African plant species traded in local, regional and international markets

\begin{tabular}{|c|c|c|}
\hline Plant species & Countries involved in trade & Reference(s) \\
\hline Achyranthes aspera & Whole plant traded in many countries including South Africa & $(38,106)$ \\
\hline Asparagus africanus & Leaves, rhizomes, roots and stems are traded in Botswana and South Africa & $(98,99,103,106)$ \\
\hline Boophone disticha & Bulbs traded in Eswatini, Lesotho, Malawi and South Africa & $(38,96,98,99,101,102,106,108,109)$ \\
\hline Burkea africana & Bark and roots traded in tropical Africa & $(105)$ \\
\hline $\begin{array}{l}\text { Colophospermum } \\
\text { mopane }\end{array}$ & Bark and seeds traded in Namibia & $(38,108)$ \\
\hline Datura stramonium & Leaves and fruits traded in South Africa and Tanzania & $(98,106,107)$ \\
\hline Dichrostachys cinerea & $\begin{array}{l}\text { Fruits and roots traded in Mozambique, South Africa, Tanzania, Zambia and } \\
\text { Zimbabwe }\end{array}$ & $(38,96,107,108)$ \\
\hline Drimia capensis & Bulbs traded in South Africa & $(106)$ \\
\hline $\begin{array}{l}\text { Gymnosporia } \\
\text { heterophylla }\end{array}$ & Roots and thorns traded in South Africa & $(101)$ \\
\hline $\begin{array}{l}\text { Helichrysum } \\
\text { nudifolium }\end{array}$ & Leaves, roots and stems traded in South Africa & $(98,101,104)$ \\
\hline Lippia javanica & Whole plant traded in Mozambique, South Africa, Tanzania and Zimbabwe & $(38,96,98,102,104,108,110)$ \\
\hline Maesa lanceolata & Bark and roots traded in South Africa & $(97,98)$ \\
\hline Ptaeroxylon obliquum & Bark traded in South Africa & $(98,100)$ \\
\hline Ricinus communis & $\begin{array}{l}\text { Cold-pressed oil and fruits traded in Burundi, Ethiopia, Mozambique, Nigeria, } \\
\text { Rwanda and South Africa }\end{array}$ & $(38,96)$ \\
\hline Searsia natalensis & Roots traded in Tanzania & $(110)$ \\
\hline $\begin{array}{l}\text { Triumfetta } \\
\text { rhomboidea }\end{array}$ & Roots traded in South Africa & (98) \\
\hline Vachellia nilotica & $\begin{array}{l}\text { Bark, leaves and roots traded in Algeria, Mozambique, South Sudan and } \\
\text { Tanzania }\end{array}$ & $(38,96,108,110)$ \\
\hline
\end{tabular}

according to the Xhosa tradition. The initiate is welcomed back to the community and the ritual concludes with a celebration of his newly acquired manhood (7). In some ethnic communities in Kenya, South Africa and Tanzania, the ritual is an integral part to many black customs and cultures $(2,8,14$, 162, 163). Circumcision is often associated with factors such as masculinity, social cohesion with boys of the same age being circumcised at the same time, self-identity and spirituality (164). Traditional male circumcision also aims at imparting strength and bravery since anaesthetics are not used, therefore, it is expected that during the act of circumcision, the initiate is expected to show that he is not feeling any pain (165). The educational sessions carried out during the ritual are aimed at disseminating traditional knowledge to the initiates, and therefore, passage of ethnic traditions to succeeding generations. Some scholars are of the view that traditional male circumcision rituals have a purpose of moulding individuals into productive and community oriented adults by guiding young people through the important stages of life $(166,167)$. It is only after circumcision that the boy can marry, own property and speak in public gatherings $(4,6,7,14$, 168, 169).

In Eastern and Southern Africa, male circumcision appears to be a common practice for a variety of reasons ranging from being an initiation ritual into adulthood, the belief that it enhances sexual pleasure to claims that it lowers the risk of HIV infection, prevents penile and cervical cancer and lowers the risk of urinary tract infection $(4,170$, 171). Studies conducted in sub-Saharan Africa show that there is high acceptability of medical circumcision even among the traditionally noncircumcising communities for health and hygiene reasons $(163,172-175)$. Factors associated with the increase of medical circumcision practices amongst the traditionally non-circumcising communities include education, personal health and hygiene, religion and ethnic mixing (172). However, among the Xhosa people in South Africa, traditional circumcision is more highly valued than medical circumcision for reasons of cultural meaning and identity $(7,168,169)$. Similar research carried out in Tanzania, revealed that traditional male circumcision is important to the social organisation and cultural identity of Kurya clans (2). According to an observation (176), traditional male circumcision is a holistic concept characterized by multiple and interconnected dimensions such as religious, spiritual, social, biomedical, aesthetic and cultural. Literature studies revealed that there is increasing demand for male circumcision in Eastern and Southern Africa and future expansion of circumcision services must be embedded within safe, affordable male circumcision procedures, sociocultural and medical determinants of circumcision.

\section{Conclusion}

This review highlights some Eastern and Southern African plant species that are widely used to treat and manage circumcision wounds. The documented plant species are therefore, an important aspect of the daily lives of many people and an important part of the Eastern and Southern African cultural heritage. The documented plant species are part of the indigenous or traditional pharmacopoeia which have ancient origins. Studies have reported that some of the species used against circumcision wounds exhibited antibacterial and anti-inflammatory properties in vitro which are the main mechanisms contributing to wound healing. However, further studies are needed such as isolation of phytochemical compounds, in vivo activities, clinical and toxicological studies to evaluate the suitability of these plant species for therapeutic use. Therefore, there is a need to subject these plant species to 
clinical studies aimed at corroborating the wound healing properties associated with management of circumcision wounds.

\section{Acknowledgements}

Funding for this research was provided by the National Research Foundation (NRF) of South Africa.

\section{Conflict of interests}

The author declares no conflict of interest.

\section{Supplementary files}

Table 1. Antibacterial and anti-inflammatory activities of Eastern and Southern African plants.

\section{References}

1. Salokoski M. How kings are made: How kingship changes: A study of rituals and ritual change in pre-colonial and colonial Owamboland, Namibia. Helsinki: Helsinki University Press; 2006.

2. Mshana G, Wambura M, Mwanga I, Mosha I, Mosha F, Changalucha J. Traditional male circumcision practices among the Kurya of north-eastern Tanzania and implications for national programmes. AIDS Care 2011;23:1111-16. https://doi.org/10.1080/09540121.2011.554518

3. Nnko S, Washija R, Urassa M, Boerma ITT. Dynamics of male circumcision practices in northwest Tanzania. Sexually Transmit Dis. 2001;28:214-18. https://doi.org/10.1097/00007435200104000-00005

4. Froneman S, Kapp PA. An exploration of the knowledge, attitudes and beliefs of Xhosa men concerning traditional circumcision. Afr I Primary Health Care Fam Med. 2017;9:a1454. https://doi.org/10.4102/phcfm.v9i1.1454

5. Prusente S, Khuzwayo N, Sikweyiya Y. Exploring factors influencing integration of traditional and medical male circumcision methods at Ingquza Hill Local Municipality, Eastern Cape: A socio-ecological perspective. Afr J Primary Health Care Fam Med. 2019;11:a1948. https://doi.org/10.4102/phcfm.v11i1.1948

6. Meel BL: Traditional male circumcision-related fatalities in Mthatha area of South Africa. Med Sci Law 2010;50:189-191. https://doi.org/10.1258/msl.2010.010017

7. Mavundla TR, Netswera FG, Bottoman B, Toth F. Rationalization of indigenous male circumcision as a sacred religious custom: Health beliefs of Xhosa men in South Africa. I Transcult Nurs. https://doi.org/10.1177/1043659609340801 2009;20:395-404

8. Drain P, Halperin D, Hughes I, Klausner I, Bailey R. Male circumcision, religion and infectious diseases: An ecologic analysis of 118 developing countries. BMC Infect Dis. 2006;6:172. https://doi.org/10.1186/1471-2334-6-172

9. Williams BG, Lloyd-Smith İO, Gouws E, Hankins C, Getz WM, Hargrove J et al. The potential impact of male circumcision on HIV in Sub-Saharan Africa. PLoS Med. 2006;3:e262. https://doi.org/10.1371/journal.pmed.0030262

10. World Health Organization/ United Nations Programme on HIV/AIDS (WHO/UNAIDS): New data on male circumcision and HIV prevention: Policy and programme implications conclusion and recommendations. Montreux: WHO/UNAIDS Technical Consultation, 2007.

11. Taylor J, Lockwood A, Taylor A. The prepuce: Specialized mucosa of the penis and its loss to circumcision. British J Urol. 1996;77:291-95. 410x.1996.85023.x

12. Marck I. Aspect of male circumcision in sub-equatorial African culture history. Health Trans Rev. 1997;7:337-59.
13. Dunsmuir WD, Goldon EM. The history of male circumcision. British J Urology Int. 1999;83:1-12.

14. Mogotlane SM, Ntlangulela JT, Ogunbanjo BG. Mortality and morbidity among traditionally circumcised Xhosa boys in the Eastern Cape Province, South Africa. Curationis 2004;27:57-62. https://doi.org/10.4102/curationis.v27i2.980

15. Doyle D. Ritual male circumcision: A brief history. I Royal College Phys., Edinburgh 2005;25:279-85.

16. Caldwell IC, Orubuloye IO, Caldwell P. Male and female circumcision in Africa from a regional to a specific Nigerian examination. Social Sci Med. 1997;44:1181-93. https://doi.org/10.1016/S0277-9536(96)00253-5

17. Hellsten SK. Rationalising circumcision: From tradition to fashion, from public health to individual freedom: Critical notes on cultural persistence of the practice of genital mutilation. J Med Ethics 2004;30:248-53. https://doi.org/10.1136 jme.2004.008888

18. Wilcken A, Keil T, Dick B. Traditional male circumcision in eastern and southern Africa: a systematic review of prevalence and complications. Bull World Health Org. 2010;88:907-14. https://doi.org/10.2471/BLT.09.072975

19. Dilika F, Meyer II. Antibacterial activity of Helichrysum pedunculatum callus cultures. S Afr J Bot. 1998:64:312-13. https://doi.org/10.1016/S0254-6299(15)30908-X

20. Dilika F, Afolayan AJ, Meyer JIM. Comparative antibacterial activity of two Helichrysum species used in male circumcision in South Africa. S Afr J Bot. 1997;63:158-59. https://doi.org/10.1016/S0254-6299(15)30728-6

21. Dilika F. The medicinal value of Amaryllidaceae and Asteraceae species used in male circumcision. PhD Thesis. Pretoria: University of Pretoria; 2002.

22. Papu J, Verster P. A biblical, cultural and missiological critique of traditional circumcision among Xhosa-speaking Christians. $\begin{array}{lll}\text { Acta } & \text { Theologica. } & \text { 2006;2:178-98. }\end{array}$ https://doi.org/10.4314/actat.v26i2.49044

23. Venter MA. Some views of Xhosa women regarding the initiation of their sons. Koers 2011;76:559-75.

24. Gray RH, Kigozi G, Serwadda D, Makumbi F, Watya S, Nalugoda $\mathrm{H}$, et al. Male circumcision for HIV prevention in men in Rakai, Uganda: A randomised trial. Lancet. 2007;369:657-66. https://doi.org/10.1016/S0140-6736(07)60313-4

25. World Health Organization (WHO). Male circumcision: Global trends and determinants of prevalence, safety and acceptability. Geneva: WHO Press; 2007.

26. Boyle GI. Hill G. Sub-Saharan African randomised clinical trials into male circumcision and HIV transmission: methodological, ethical and legal concerns. J Law Med. 2011;19:316-34.

27. Kilima SP, Shayo HE, Msovela I, Senkoro KP, Mayala BK Mboera LEG et al. The potential of involving traditional practitioners in the scaling up of male circumcision in the context of HIV prevention in Tanzania. Tanzania J Health Res. 2012;14:48-60. https://doi.org/10.4314/thrb.v14i1.9

28. Mutabazi V, Kaplan SA, Rwamasirabo E, Bitega JP, Ngeruka ML, Savio D et al. HIV prevention: Male circumcision comparison between a nonsurgical device to a surgical technique in resource-limited settings: A prospective, randomized, nonmasked trial. I] Acquired Immune Def Syndr. 2012;61:49-55. https://doi.org/10.1097/QAI.0b013e3182631d69

29. Mwashambwa YM, Mwampagatwa IH, Rastegaev A, Gesase AP. The male circumcision: The oldest ancient procedure, its past, present and future roles. Tanzania I Health Res 2013;15:199204. https://doi.org/10.4314/thrb.v15i3.8

30. Chikutsa A, Maharaj P. Social representations of male circumcision as prophylaxis against HIV and AIDS in Zimbabwe. BMC Public Health 2015, 15:603. https://doi.org/10.1186/s12889-015-1967-z

31. Rugwiji TT. Circumcision and prevention of HIV and AIDS in Zimbabwe: Male genital cutting as a religio-cultural rite. $\begin{array}{lll}\text { Theolog } & \text { Stud. } & \text { 2018:74:4848. }\end{array}$ http://dx.doi.org/10.4102/hts.v74i1.4848

32. Van Wyk BE, Van Oudtshoorn B, Gericke N. Medicinal plants of South Africa. Pretoria: Briza Publications; 2013. 
33. Light ME, Sparg SG, Stafford GI, Van Staden I. Riding the wave: South Africa's contribution to ethnopharmacological research over the last 25 years. I Ethnopharmacol. 2005;100:127-30. https://doi.org/10.1016/i.jep.2005.05.028

34. Mulholland DA. The future of ethnopharmacology: A southern African perspective. J Ethnopharmacol. 2005;100:124-26. https://doi.org/10.1016/j.jep.2005.05.013

35. Karou D, Nadembega WMC, Ouattara L, Ilboudo DP, Canini A Nikiéma JB, et al. African ethnopharmacology and new drug discovery. Med Aromatic Plant Sci Biotechnol. 2007;1:1-7.

36. Van Wyk B-E. A review of Khoi-San and Cape Dutch medical ethnobotany. I Ethnopharmacol. 2008;119:331-41. https://doi.org/10.1016/j.jep.2008.07.021

37. Van Wyk B-E. A broad review of commercially important southern African medicinal plants. I Ethnopharmacol. 2008;119:342-55. https://doi.org/10.1016/j.jep.2008.05.029

38. Van Wyk B-E. A review of African medicinal and aromatic plants. In Medicinal and aromatic plants of the world: Africa, volume 3. Edited by Neffati M, Naịjaa H, Máthé Á. Dordrecht: Springer 2017:19-60.

39. Watt İM, Breyer-Brandwị̂k MG. The medicinal and poisonous plants of southern and eastern Africa. Edinburgh: E \& S Livingstone; 1962.

40. Hutchings A, Scott AH, Lewis G, Cunningham A. Zulu medicinal plants: An inventory. Pietermaritzburg: University of Natal Press; 1996.

41. Maundu P, Berger D, Ole Saitabau C, Nasieku I, Kipelian M, Mathenge S et al. Ethnobotany of the Loita Maasai: Towards community management of the forest of the lost child: Experiences from the Loita ethnobotany project. Paris: People and Plants Working Paper 8, UNESCO; 2001.

42. Schmelzer GH. Acalypha ornata Hochst. ex A. Rich. In Plant resources of tropical Africa 11: Medicinal plants 1. Edited by Schmelzer GH, Gurib-Fakim A. Leiden:Backhuys Publishers; 2008:26-27.

43. Kokwaro IO. Medicinal plants of East Africa. Nairobi: University of Nairobi Press; 2009.

44. Moffett R. Sesotho plant and animal names and plants used by the Basotho. Bloemfontein: Sun Press; 2010.

45. Roberts M, Roberts S. Indigenous healing plants. Pretoria: Briza Publications; 2017.

46. Randall RP. A global compendium of weeds. Perth: Western Australia: Department of Agriculture and Food; 2017.

47. Stepp IR, Moerman DE. The importance of weeds in ethnopharmacology. I Ethnopharmacol. 2001;75:19-23. https:// doi.org/10.1016/S0378-8741(00)00385-8

48. Nịoroge NG, Bussmann WR, Gemmill B, Newton LE, Ngumi VW. Utilisation of weed species as sources of traditional medicines in central Kenya. Lyonia 2004;7:71-87.

49. Palmer CT. The inclusion of recently introduced plants in the Hawaiian ethnopharmacopoeia. Econ Bot. 2004;58:280-93. https://doi.org/10.1663/0013-0001(2004)58[S280:TIORIP]2.0.CO;2

50. Alencar NL, de Sousa Araujo TA, de Amorim ELC, de Albuquerque UP. The inclusion and selection of medicinal plants in traditional pharmacopoeias-evidence in support of the diversification hypothesis. Econ Bot. 2010;64:68-79. https:/ doi.org/10.1007/s12231-009-9104-5

51. Alencar NL, Santoro FR, Albuquerque UP. What is the role of exotic medicinal plants in local medical systems? A study from the perspective of utilitarian redundancy. Rev Brasil Farmacogn. https://doi.org/10.1016/ị.bịp.2014.09.003

52. Maroyi A. Ethnomedicinal uses of exotic plant species in southcentral Zimbabwe. Indian I Trad Knowl, 2018;17:71-77.

53. Bennett BC, Prance GT. Introduced plants in the indigenous pharmacopoeia of Northern South America. Econ Bot 2000;54:90-102. https://doi.org/10.1007/BF02866603

54. Hedberg I, Hedberg O, Madati PJ, Mshigeni KE, Mshiu EN, Samuelson G. Inventory of plants used in traditional medicine in Tanzania. 1. Plants of the families Acanthaceae -
Cucurbitaceae. J Ethnopharmacol. 1982;6:29-60. https://doi.org/ 10.1016/0378-8741(82)90070-8

55. Bussmann RW, Gilbreath GG, Solio J, Lutura M, Lutuluo R, Kunguru $\mathrm{K}$ et al. Plant use of the Maasai of Sekenani valley, Maasai Mara, Kenya. I Ethnobiol Ethnomed. 2006;2:22. https:// doi.org/10.1186/1746-4269-2-22

56. Nankaya I, Nampushi I, Petenya S, Balslev H. Ethnomedicinal plants of the Loita Maasai of Kenya. Env Devel Sustain. 2020;22:2569-89. https://doi.org/10.1007/s10668-019-00311-w

57. Dilika NF, Nikolova RV, Jacobs TV. Plants used in the circumcision rites of the Xhosa tribe in South Africa. Acta Hortic 1996:426:165-70. https://doi.org/10.17660/ActaHortic.1996.426.18

58. Grierson DS, Afolayan AIT. An ethnobotanical study of plants used for the treatment of wounds in the Eastern Cape, South Africa. I I Ethnopharmacol. 1999;67:327-32. https://doi.org/10.1016/s0378-8741(99)00082-3

59. Cocks ML, Dold AP. Cultural significance of biodiversity: The role of medicinal plants in urban African cultural practices in the Eastern Cape, South Africa. I Ethnobiol. 2006;26:60-81. https://doi.org/10.2993/0278-0771(2006)26[60:CSOBTR]2.0.CO;2

60. Van Wyk B-E, De Wet H, Van Heerden FR. An ethnobotanical survey of medicinal plants in the southeastern Karoo, South Africa. S Afr I Bot. 2008;74:696-704. https://doi.org/10.1016/j.saj̣b.2008.05.001

61. Maroyi A. Diversity of use and local knowledge of wild and cultivated plants in the Eastern Cape province, South Africa. Ethnobiol Ethnomed. https://doi.org/10.1186/s13002-017-0173-8

62. Nair IJ, Van Staden J, Bonnet SL, Wilhelm A. Distribution and diversity of usage of the Amaryllidaceae in the traditiona remediation of infectious diseases. Nat Prod Comm. 2017;12:635-39

63. Van Wyk B-E, Gericke N. People's plants: A guide to useful plants of southern Africa. Pretoria: Briza Publications; 2018.

64. Hutchings A, Johnson C. Glimpses of a Xhosa herbal. Veld Flora 1986;72:59-62.

65. Hutchings A. Some observations on plant usage in Xhosa and Zulu medicine. Bothalia 1989;19:225-35. https://doi.org/10.4102/ abc.v19i2.965

66. Bhat RB, Jacobs TV. Traditional herbal medicine in Transkei. J Ethnopharmacol. 1995;48:7-12. https://doi.org/10.1016/03788741(95)01276-ị.

67. Semenya SS, Potgieter MI, Tshisikhawe MP. Use, conservation and present availability status of ethnomedicinal plants of Matebele village in the Limpopo province, South Africa. Afr I Biotechnol.

https://doi.org/10.5897/AỊB12.2572n

68. Semenya SS, Potgieter MI. Bapedi traditional healers in the Limpopo province, South Africa: Their socio-cultural profile and traditional healing practice. I Ethnobiol Ethnomed. 2014;10:4. https://doi.org/10.1186/1746-4269-10-4

69. Bainbridge H. Indigenous use of mopane (Colophospermum mopane) in northwestern Namibia. Desert Pl. 2012;28:23-26.

70. Brumbaugh MA. Medicinal plants of Namibia. BSc Honours Thesis. Tucson: University of Arizona; 2015.

71. Philander LA. An ethnobotany of Western Cape Rasta bush medicine. J Ethnopharmacol. 2011;138:578-94. https://doi.org/10.1016/i.jep.2011.10.004

72. Dold AP, Cocks ML. The medicinal use of some weeds, problem and alien plants in the Grahamstown and Peddie districts of the Eastern Cape. South Africa. S Afr I Sci. 2000:96:467-73.

73. Hedberg I, Hedberg O, Madati PI, Mshigeni KE, Mshiu EN, Samuelson G. Inventory of plants used in traditional medicine in Tanzania. 2. Plants of the families Dilleniaceae - Opiliaceae. I Ethnopharmacol. 1983;9:105-28. https://doi.org/10.1016/0378 8741(83)90030-2

74. Simon, C, Lamla, M. Merging pharmacopoeia: Understanding the historical origins of incorporative pharmacopoeia1 processes among Xhosa healers in Southern Africa. I 
Ethnopharmacol. 1991;33:231-42. https://doi.org/10.1016/03788741(91)90083-p

75. Bhat RB. Plants of Xhosa people in the Transkei region of Eastern Cape (South Africa) with major pharmacological and therapeutic properties. I Med Pl Res. 2013;7:1474-80. https://doi.org/10.5897/IMPR12. 973

76. Suntar I. The medicinal value of Asteraceae family plants in terms of wound healing activity. Fabad I Pharm Sci. 2014;39:21-31.

77. Gerstner I. A preliminary checklist of Zulu names of plants with short notes. Bantu Stud. 1938;12:215-36. https://doi.org/ 10.1080/02561751.1938.9676078

78. Swelankomo N. Helichrysum foetidum (L.) Moench; 2021. Available from: http://pza.sanbi.org/helichrysum-foetidum accessed on 7 January 2020

79. Maroyi A. Medicinal uses, biological and phytochemical properties of Helichrysum foetidum (L.) Moench (Asteraceae). Asian J Pharmaceut Clinical Res. 2019;12:13-18. https://doi.org/ 10.22159/aịpcr.2019.v12i7.33607

80. Xaba PM. Helichrysum nudifolium (L.) Less; 2021. Available from: http://pza.sanbi.org/helichrysum-nudifolium, accessed on 12 Ianuary 2021.

81. Sewani-Rusike CR, Mammen M. Medicinal plants used as home remedies: A family survey by first year medical students. Afr Trad Compl Alt Med. 2014;11:67-72. https://doi.org/10.4314/aịtcam.v11i5.11

82. Maroyi A. Helichrysum nudifolium (L.) Less.: review of its medicinal uses, phytochemistry and biological activities. I Pharm Nutr Sci. 2019;9:189-94. https://doi.org/120.29169/19275951.2019.09.03.8

83. Bolofo RN, Johnson CT. The identification of 'isicakathi' and its medicinal use in Transkei. Bothalia 1988;18:125-30. https://doi.org/10.4102/abc.v18i1.995

84. Meyer JJM, Dilika F. Antibacterial activity of Helichrysum pedunculatum used in circumcision rites. I Ethnopharmacol. 1996:53:51-54. https://doi.org/10.1016/0378-8741(96)01411-0

85. Van Vuuren CI, De Jongh M. Rituals of manhood in South Africa: Circumcision at the cutting edge of critical intervention. S Afr J Ethnol. 1999;22:142-56.

86. Dilika F, Bremner PD, Meyer IIM. Antibacterial activity of linoleic and oleic acids isolated from Helichrysum pedunculatum: A plant used during circumcision rites Fitoterapia 2000;71:450-52. https://doi.org/10.1016/s0367326x(00)00150-7

87. Bhat RB. Medicinal plants and traditional practices of Xhosa people in the Transkei region of Eastern Cape, South Africa. Indian I Trad Knowl. 2014;13:292-98.

88. Maroyi A. Helichrysum longifolium and H. pedunculatum: A comparative analysis of their medicinal uses, chemistry and biological activities. Asian I Pharmaceut Clinical Res. 2019;12:41-46. https://doi.org/10.22159/ajpcr.2019.v12i7.33684

89. Hutchings A. Ritual cleansing, incense and the tree of life: Observations on some indigenous plant usage in traditional Zulu and Xhosa purification and burial rites. Alternation 2007;14:189-218.

90. Maroyi A. Lippia javanica (Burm. f.) Spreng: Traditional and commercial uses, phytochemical and pharmacological significance. Evidence-Based Compl Alt Med. 2017; article ID 6746071. https://doi.org/10.1155/2017/6746071

91. Mabogo DEN. The ethnobotany of the Vhavenda. MSc Thesis. Pretoria: University of Pretoria; 1990.

92. Oyedemi SO, Oyedemi BO, Falowo AB, Fayemi PO, Coopoosamy RM. Antibacterial and ciprofloxacin modulating activity of Ptaeroxylon obliquum (Thunb.) Radlk leaf used by the Xhosa people of South Africa for the treatment of wound infections Biotechnol Biotechnolog Equipm. 2016;30:1006-15. https:// doi.org/10.1080/13102818.2016.1209434

93. Chhabra SC, Mahunnah RLA, Mshiu EN. Plants used in traditional medicine in Eastern Tanzania. VI. Angiosperms (Sapotaceae to Zingiberaceae). J Ethnopharmacol. 1993;39:83103. https://doi.org/10.1016/0378-8741(93)90024-y
94. Bosch CH. Triumfetta rhomboidea Jacq. In Plant resources of tropical Africa 16: Fibres. Edited by Brink M, Achigan-Dako EG. Leiden: Backhuys Publishers 2012:446-49.

95. Kiringe JW. A survey of traditional health remedies used by the Maasai of southern Kaijiado district, Kenya. Ethnobot Res Appl. 2006;4:61-73.

96. Cunningham AB. African medicinal plants: Setting priorities at the interface between conservation and primary health care. Paris: People and Plants Working Paper 1, UNESCO; 1993.

97. Mander M. Marketing of indigenous medicinal pants in South Africa: A case study in KwaZulu-Natal. Rome: FAO 1998.

98. Williams VL, Balkwill K, Witkowski ET. A lexicon of plants traded in the Witwatersrand umuthi shops. Bothalia 2001;31:71-98. https://doi.org/10.4102/abc.v31i1.508

99. Dold AP, Cocks ML. The trade in medicinal plants in the Eastern Cape province, South Africa. S Afr I Sci. 2002;98:589-97.

100. Loundou P. Medicinal plant trade and opportunities for sustainable management in South Africa. MSc Thesis. Stellenbosch: University of Stellenbosch; 2008.

101. Botha I, Weiersbye IM. Ethnobotanic and forage uses of plants on mine properties in the Witwatersrand basin gold fields, South Africa. In Mine Closure. Edited by Fourie A, Tibbett M, Wiertz I. Perth: Australian Centre for Geomechanics 2010:325 42 .

102. Moeng ET. An investigation into the trade of medicinal plants by Muthi shops and street vendors in the Limpopo province, South Africa. MSc Thesis. Mankweng: University of Limpopo; 2010.

103. Setshogo MP, Mbereki CM. Floristic diversity and use of medicinal plants sold by street vendors in Gaborone, Botswana. Afr I Pl Sci Biotechnol. 2011;5:69-74.

104. Van Wyk B-E. The potential of South African plants in the development of new medicinal products. S Afr I Bot 2011;77:812-29. https://doi.org/10.1016/ị.saịb.2011.08.011

105. Maroyi A. Burkea africana Hook. In Plant resources of tropical Africa 7: Timbers 2. Edited by Lemmens RHMI, Louppe D Oteng-Amoako AA. Leiden: Backhuys Publishers 2012:174-77.

106. Petersen LM, Moll EI, Collins R, Hockings MT. Development of a compendium of local, wild-harvested species used in the informal economy trade, Cape Town, South Africa. Ecol Soc. 2012;17:26. http://dx.doi.org/10.5751/ES-04537-170226

107. Posthouwer C. Medicinal plants of Kariakoo market, Dar es Salaam. Tanzania. MSc Thesis. Leiden: Leiden University: 2015.

108. Van Wyk B-E. A review of commercially important African medicinal plants. I Ethnopharmacol. 2015;176:118-34. https://doi.org/10.1016/ị.jep.2015.10.031

109. Hilonga S, Otieno IN, Ghorbani A, Pereus D, Kocyan A, de Boer $\mathrm{H}$. Trade of wild-harvested medicinal plant species in local markets of Tanzania and its implications for conservation. S Afr I $\quad$ Bot. 2019;122:214-24. https://doi.org/10.1016/j.j.sajb.2018.08.012

110. Rasethe MT, Semenya SS, Maroyi A. Medicinal plants traded by informal herbal medicine markets in the Limpopo province, South Africa. Evidence-Based Compl Alt Med. Volume 2019:article ID 2609532. https://doi.org/10.1155/2019/2609532

111. Vasisht K, Sharma N, Karan M. Current perspective in the international trade of medicinal plants material: An update. Current Pharmaceut Design 2016;22:4288-36. https://doi.org/ $10.2174 / 1381612822666160607070736$

112. Houghton PI. Hylands PI. Mensah AY. Hensel A. Deters A. In vitro tests and ethnopharmacological investigations: wound healing as an example. I Ethnopharmacol. 2005;100:100-07. https://doi.org/10.1016/i.jep.2005.07.001

113. Agyare C, Asase A, Lechtenberg M, Niehues M, Deters A, Hensel A. An ethnopharmacological survey and in vitro confirmation of ethnopharmacological use of medicinal plants used for wound healing in Bosomtwi-Atwima-Kwanwoma area, Ghana. J Ethnopharmacol. 2009;125:393-403. https://doi.org/10.1016/ị.jep.2009.07.024 
114. Walmsley GG, Maan ZN, Wong VW, Duscher D, Hu MS, Zielins ER et al. Scarless wound healing: Chasing the holy grail. Plast Reconstr Surg. https://doi.org/10.1097/PRS.0000000000000972 2015;135:907-17

115. Chingwaru C, Bagar T, Maroyi A, Kapewangolo PT, Chingwaru W. Wound healing potential of selected Southern African medicinal plants. I Herbal Med. 2019;17:100263. https://doi.org/ 10.1016/i.hermed.2019.100263

116. Teka A, Rondevaldova J, Asfaw Z, Demissew S, Van Damme P, Kokoska L et al. In vitro antimicrobial activity of plants used in traditional medicine in Gurage and Silti Zones, south central Ethiopia. BMC Compl Alt Med. 2015;15:286. https://doi.org/ 10.1186/s12906-015-0822-1

117. Madikizela B, Ndhlala AR, Finnie JF, Van Staden J. In vitro antimicrobial activity of extracts from plants used traditionally in South Africa to treat tuberculosis and related symptoms. Evidence-Based Compl Alt Med. 2013;Volume 2013:article ID 840719. https://doi.org/10.1155/2013/840719

118. Madikizela B, Ndhlala AR, Finnie J̦F, Van Staden I. Antimycobacterial, anti-inflammatory and genotoxicity evaluation of plants used for the treatment of tuberculosis and related symptoms in South Africa. I Ethnopharmacol. 2014 153:386-91. https://doi.org/10.1016/i.jep.2014.02.034

119. Pandey R, Sambasivarao Y, Gurumurthy A. Antibacterial activity of medicinal plants against pathogens from extracts of Achyranthes aspera. Med Aromat Plants 2013;2:5. https://doi.org/10.4172/2167-0412.1000135

120. Nigussie D, Davey G, Legesse BA, Fekadu A, Makonnen E. Antibacterial activity of methanol extracts of the leaves of three medicinal plants against selected bacteria isolated from wounds of lymphoedema patients. BMC Compl Med Therapies 2021;21:2. https://doi.org/10.1186/s12906-020-03183-0

121. Khuda F, Iqubal Z, Khan A, Zakiullah A, Nasir F, Shah Y. Antiinflammatory activity of the topical preparation of Valeriana wallichii and Achyranthes aspera leaves. Pak I Pharm Sci. 2013;26:451-54

122. Emeka PM, Badger-Emeka LI, Fateru F. In vitro antimicrobia activities of Acalypha ornata leaf extracts on bacterial and fungal clinical isolates. I Herbal Med. 2012:2:136-42. https:// doi.org/10.1016/i.hermed.2012.09.001

123. Steenkamp V, Fernandes AC, Van Rensburg CE. Antibacteria activity of Venda medicinal plants. Fitoterapia 2007, 78:561-64. https://doi.org/10.1016/i.fitote.2007.02.014

124. Dzoyem IP, Eloff IN. Anti-inflammatory, anticholinesterase and antioxidant activity of leaf extracts of twelve plants used traditionally to alleviate pain and inflammation in South Africa. I Ethnopharmacol. 2015;160:194-201. https://doi.org/10.1016/i.jep.2014.11.034

125. Mabona U, Viljoen A, Shikanga E, Marston A, Van Vuuren S. Antimicrobial activity of southern African medicinal plants with dermatological relevance: From an ethnopharmacological screening approach, to combination studies and the isolation of a bioactive compound. I Ethnopharmacol. 2013;148:45-55. https://doi.org/10.1016/i.jep.2013.03.056

126. Shale TL, Stirk WA, Van Staden I. Screening of medicinal plants used in Lesotho for anti-bacterial and anti-inflammatory activity. I Ethnopharmacol _ 1999:67:347-54. https://doi.org/10.1016/s0378-8741(99)00035-5

127. Jäger AK, Hutchings A, Van Staden I. Screening of Zulu medicinal plants for prostaglandin-synthesis inhibitors. Ethnopharmacol. 1996;52:95-100. https://doi.org/10.1016/03788741(96)01395-5

128. Kaarina IN, Dan K. Secilia IK. Antipseudomonal potential of Colophospermum mopane and Acrotome inflata, medicina plants indigenous to Namibia. Afr I Pharm Pharmacol. 2017:11:78-86. https://doi.org/10.5897/AỊPP2016.4716

129. Mudzengi CP, Murwira A, Tivapasi M, Murungweni C, Burumu IV, Halimani T. Antibacterial activity of aqueous and methanol extracts of selected species used in livestock health management. Pharm Biol. 2017;55:1054-60. https://doi.org/10.1080/13880209.2017.1287744

130. Shandukani PD, Tshidino SC, Masoko P, Moganedi KM Antibacterial activity and in situ efficacy of Bidens pilosa Linn and Dichrostachys cinerea Wight et Arn extracts against common diarrhoea-causing waterborne bacteria. BMC Comp Alt Med. 2018;18:171. https://doi.org/10.1186/s12906-018-2230-9

131. Nciki S, Vuuren S, Van Eyk A, De Wet H. Plants used to treat skin diseases in northern Maputaland, South Africa: Antimicrobial activity and in vitro permeability studies. Pharm Biol. 2016;54:2420-36 https://doi.org/10.3109/13880209.2016.1158287

132. McGaw LI, Jäger AK, Van Staden I. Prostaglandin synthesis inhibitory activity in Zulu, Xhosa and Sotho medicinal plants. Phytoth Res. 1997;11:113-17. https://doi.org/10.1002/(SICI)1099 1573(199703)11:2<113::AID-PTR27>3.0.CO;2-S

133. Eftekhar F, Yousefzadi M, Tafakori V. Antimicrobial activity of Datura innoxia and Datura stramonium. Fitoterapia 2005;76:118-20. https://doi.org/10.1016/i.fitote.2004.10.004

134. Taye B, Giday M, Animut A, Seid I. Antibacterial activities of selected medicinal plants in traditional treatment of human wounds in Ethiopia. Asian Pac I Trop Biomed. 2011;1:370-75 https://doi.org/10.1016/S2221-1691(11)60082-8

135. Obi CL, Potgieter N, Randima LP, Mavhungu NI, Musie E, Bessong PO, et al. Antibacterial activities of five plants against some medically significant human bacteria. S Afr I Sci. 2002;98:25-28.

136. Ondua M, Njoya EM, Abdalla MA, McGaw LI. Antiinflammatory and antioxidant properties of leaf extracts of eleven South African medicinal plants used traditionally to treat inflammation. J Ethnopharmacol. 2019;234:27-35. https:// doi.org/10.1016/ị.jep.2018.12.030

137. Lourens ACU, Van Vuuren SF, Viljoen AM, Davids H, Van Heerden FR. Antimicrobial activity and in vitro cytotoxicity of selected South African Helichrysum species. S Afr I Bot 2011;77:229-35. https://doi.org/10.1016/ị.saịb.2010.05.006

138. Aiyegoro OA, Afolayan AI, Okoh AI. In vitro antibacterial activities of crude extracts of the leaves of Helichrysum longifolium in combination with selected antibiotics. Afr Pharm Pharmacol. 2009;3:293-300.

139. Aiyegoro OA, Afolayan AI, Okoh AI. Studies on the in vitro time kill assessment of crude acetone and aqueous extracts of Helichrysum pedunculatum leaves. Afr I Biot. 2008;7:3718-22. https://doi.org/10.5897/AJ̣B08.578

140. Shikanga EA, Combrinck S, Regnier T. South African Lippia herbal infusions: Total phenolic content, antioxidant and antibacterial activities. S Afr I Bot. 2010;76:567-71. https://doi.org/10.1016/ị.saịb.2010.04.010

141. York T, Van Vuuren SF, De Wet H. An antimicrobial evaluation of plants used for the treatment of respiratory infections in rural Maputaland, KwaZulu-Natal, South Africa. I Ethnopharmacol.

https://doi.org/10.1016/i.jep.2012.08.038

2012;144:118-27.

142. Asowata-Ayodele AM, Otunola GA, Afolayan AI. Assessment of the polyphenolic content, free radical scavenging, antiinflammatory, and antimicrobial activities of acetone and aqueous extracts of Lippia javanica (Burm.f.) Spreng Pharmacogn Mag. 2016;12:353-62. https://doi.org/10.4103/0973 1296.185770

143. Elisha IL, Botha FS, McGaw LI, Eloff IN. The antibacterial activity of extracts of nine plant species with good activity against Escherichia coli against five other bacteria and cytotoxicity of extracts. BMC Compl Alt Med. 2017:17:133 https://doi.org/10.1186/s12906-017-1645-Z

144. Adamu M, Naidoo V, Eloff JN. The antibacterial activity antioxidant activity and selectivity index of leaf extracts of thirteen South African tree species used in ethnoveterinary medicine to treat helminth infections. BMC Vet Res. 2014:10:52 https://doi.org/10.1186/1746-6148-10-52.

145. Madikizela B, Ndhlala AR, Finnie IF, Van Staden I. Ethnopharmacological study of plants from Pondoland used against diarrhoea. I Ethnopharmacol. 2012;141:61-71. https://doi.org/ 10.1016/i.jep.2012.01.053

146. Elisha IL, Dzoyem JP, McGaw LI, Botha FS, Eloff JN. The antiarthritic, anti-inflammatory, antioxidant activity and relationships with total phenolics and total flavonoids of nine South African plants used traditionally to treat arthritis. BMC Compl Alt Med. 2016;16:307. https://doi.org/10.1186/s12906-016 1301-z 
147. Ramadwa TE, Awouafack MD, Sonopo MS, Eloff JN. Antibacterial and antimycobacterial activity of crude extracts, fractions, and isolated compounds from leaves of sneezewood, Ptaeroxylon obliquum (Rutaceae). Nat Prod Comm. 2019;14:1-7. https://doi.org/10.1177/1934578X19872927

148. Soyelu OT, Masika PI. Antibacterial and antioxidant activities of some selected plants used for the treatment of cattle wounds in the Eastern Cape. Afr I Biot. 2012;11:3476-81. https://doi.org/ 10.5897/AJB10.1070

149. Iqubal I, Zaib S, Farooq U, Khan A, Bibi I, Suleman S. Antioxidant, antimicrobial and free radical scavenging potential of aerial parts of Periploca aphylla and Ricinus communis. ISRN Pharmacol. 2012;article ID 563267. https://doi.org/10.5402/2012/563267

150. Umaarasu T, Padmavathy K, Thirunavukkarasu D, Rajesh SV, Govindaraj I, Shanmugam G. Evaluation of the antimicrobial activity and phytochemical investigation of the leaf extracts of Ricinus communis Linn. against drug-resistant bacterial pathogens. Drug Invention Tod. 2019;11:1299-1303.

151. Suurbaar I, Mosobil R, Donkor A-M. Antibacterial and antifungal activities and phytochemical profile of leaf extract from different extractants of Ricinus communis against selected pathogens. BMC Res Notes 2017;10:660. https://doi.org/ 10.1186/s13104-017-3001-2

152. Kareru PG, Gachanja AN, Keriko IM, Kenji GM. Antimicrobial activity of some medicinal plants used by herbalists in Eastern province. Kenva. Afr I Trad Compl Alt Med. 2008:5:51-55. https://doi.org/10.4314/ajtcam.v5i1.31256

153. Korir R, Kimani C, Gathirwa I, Wambura M, Bii C. In vitro antimicrobial properties of methanol extracts of three medicinal plants from Kilifi district, Kenya. Afr I Health Sci. 2012;20:4-10

154. Devmurari VP, Ghodasara TJ, Jivani NP. Antibacterial activity and phytochemical study of ethanolic extract of Triumfetta rhomboidea Jacq. Int J Pharmaceut Sci Drug Res. 2010;2:40-42. https://ijpsdr.com/index.php/ijpsdr/article/view/77

155. Odimegwu CD, Uche IF, Ozioko CL, Ogbuanya CE, Gugu HT, Esimone OC. In vitro antimicrobial evaluation of methanol extract of Triumfetta rhomboidea leaves against some clinical bacterial isolates. Int J Biol Chem Sci. 2011;5:1970-77. https://doi.org/10.4314/ịbcs.v5i5.17

156. Thawkar B, Kale M, Oswal M, Maniyar K, Kadam K, Kamat S. To study anti-inflammatory activity of $70 \%$ methanolic extract of Triumfetta rhomboidea: In vitro study. Res I Pharm Tech. 2016;9:241-44. https://doi.org/10.5958/0974-360X.2016.00044.5

157. Larsen BHV, Soelberg I, Jäger AK. COX-1 inhibitory effect of medicinal plants of Ghana. S Afr I Bot. 2015;99:129-31. https://doi.org/10.1016/j.sajb.2015.04.004

158. Kaur G, Sharma AK, Karnwal A. Antimicrobial activity of Acacia nilotica against various clinical isolates. Elixir Appl Bot. 2016:97:42260-262.

159. Gmaraldeen SM, Magzoub AA, Badri AM, Garbi MI, Saleh MS Antibacterial activity of Acacia nilotica fruits extract against pathogenic bacteria. Int I Appl Res. 2016;2:103-06.

160. Eldeen IMS, Elgorashi EE, Van Staden I. Antibacterial, antiinflammatory, anticholinesterase and mutagenic effects of extracts obtained from some trees used in South African traditional medicine. I Ethnopharmacol. 2005;102:457-64. https://doi.org/10.1016/j.jep.2005.08.049

161. Turner VW. The ritual process. Chicago: Aldine; 1969.

162. Carstens P. The socio-economic context of initiation ceremonies among two Southern African people. Canadian J Afr Stud. 1982;16:505-22.

$10.1080 / 00083968.1982 .10804010$

https://doi.org/

163. Weiss HA, Plummer ML, Changalucha I, Mshana G, Shigongo ZS, Todd J et al. Circumcision among adolescent boys in rural northwestern Tanzania. Trop Med Int Health 2008;13:1054-61. https://doi.org/10.1111/i.1365-3156.2008.02107.x

164. Niang IC, Boiro $\mathrm{H}$. You can also cut my finger!: Social construction of male circumcision in West Africa, a case study of Senegal and Guinea Bissau. Reprod Health Matters 2007;15:22-32. https://doi.org/10.1016/S0968-8080(07)29312-7

165. Wambura M, Mwanga JR, Mosha JF, Mshana G, Mosha F, Changalucha J. Acceptability of medical male circumcision in the traditionally circumcising communities in Northern Tanzania. BMC Public Health 2011;11:373. https://doi.org/10.1186/1471-2458-11-373

166. Munthali AC, Zulu EM. The timing and role of initiation rites in preparing young people for adolescence and responsible sexual and reproductive behaviour in Malawi. Afr I Reprod Health 2007;11:150-67.

167. Maposa RS. Going under the traditional knife: Linking African traditional education and the ethic of identity through Shangani culture, Zimbabwe. I Emerging Trends Educ Res Policy Stud 2011;2:479-84.

168. Vincent L. Boys will be boys: Traditional Xhosa male circumcision, HIV and sexual socialisation in contemporary South Africa. Cult Health Sex. 2008;10:431-46. https://doi.org/10.1080/13691050701861447

169. Peltzer K, Kanta X. Medical circumcision and manhood initiation rituals in the Eastern Cape, South Africa: A post intervention evaluation. Cult Health Sex. 2009;11:83-97. https:/! doi.org/10.1080/13691050802389777

170. Mensch BS, Bagah D, Clark WH, Binka F. The changing nature of adolescence in the Kassena-Nankana district of northern Ghana. Stud Family Plan. 1999;30:95-111. https://doi.org/10.1111/i.1728-4465.1999.00095.x

171. Meissner O, Buso DL. Traditional male circumcision in the Eastern Cape: Scourge or blessing? S Afr Med I. 2007;97:371-73.

172. Nnko S, Washija R, Urassa M, Boerma JT. Dynamics of male circumcision practices in northwest Tanzania. Sexually Transmit Dis. 2001;28:214-18. https://doi.org/10.1097/00007435200104000-00005

173. Bailey R, Muga R, Poulussen R, Abicht H. The acceptability of male circumcision to reduce HIV infections in Nyanza province, Kenya. AIDS Care 2002;14:27-40. https://doi.org/10.1080/09540120220097919

174. Kebaabetswe P, Lockman S, Mogwe S, Mandevu R, Thior I, Essex $\mathrm{M}$ et al. Male circumcision: An acceptable strategy for HIV prevention in Botswana. Sexually Transmit Infect. 2003;79:214-19. http://dx.doi.org/10.1136/sti.79.3.214

175. Westercamp N, Bailey RC. Acceptability of male circumcision for prevention of HIV/AIDS in sub-Saharan Africa: A review. AIDS Behavior. 2007;11:341-55 http://dx.doi.org/10.1080/09540120220097919

176. Peltzer K, Niang CI, Muula AS, Bowa K, Okeke L, Boiro H et al. Male circumcision, gender and HIV prevention in sub-Saharan Africa: A (social science) research agenda. I Social Aspects HIV AIDS 2007;4:658-67. $10.1080 / 17290376.2007 .9724889$ http://dx.doi.org/

\section{Additional information}

Peer review information: Plant Science Today thanks Sectional Editor and the other anonymous reviewers for their contribution to the peer review of this work.

Reprints and permissions information is available at https://horizonepublishing.com/journals/index.php/PST/open_access_policy

Publisher's Note: Horizon e-Publishing Group remains neutral with regard to jurisdictional claims in published maps and institutional affiliations.

To cite this article: Maroyi A. Use of herbal formulations for the treatment of circumcision wounds in Eastern and Southern Africa. Plant Science Today. 2021;8(3):517-527. https://doi.org/10.14719/pst.2021.8.3.1126

Plant Science Today, published by Horizon e-Publishing Group, is covered by Scopus, Web of Science, BIOSIS Previews, Clarivate Analytics, etc. See https://horizonepublishing.com/journals/index.php/PST/indexing_abstracting 